\section{Treatment of osteomalacia associated with primary biliary cirrhosis with oral 1-alpha-hydroxy vitamin $\mathrm{D}_{3}$}

Osteomalacia sometimes occurs in chronic cholestatic liver disease and is usually treated with large doses of parenteral vitamin $D$, although oral treatment is also effective. ${ }^{1}$ Treatment with oral $1 \alpha$-hydroxy vitamin $\mathrm{D}_{3}\left(1 \alpha-\mathrm{OHD}_{3}\right)$, a synthetic analogue of 1,25 dihydroxy vitamin $D_{3}$, is of particular interest in liver disease since a therapeutic effect depends on its intestinal absorption and hepatic 25 -hydroxylation, ${ }^{2}$ both of which may be impaired in severe chronic cholestasis. We report the biochemical and histological responses to six months' treatment with oral $1 \alpha-\mathrm{OHD}_{3}$ in a patient with primary biliary cirrhosis (PBC) and severe osteomalacia.

\section{Case history}

In 1976 a 65 -year-old woman presented with pruritus and jaundice. Liver biopsy showed changes consistent with late PBC, and antimitochondrial antibodies were present. Subsequently the serum bilirubin concentration remained between 50 and $103 \mu \mathrm{mol} / 1(2.9$ and $6.0 \mathrm{mg} / 100 \mathrm{ml}$ ) (normal $3-20 \mu \mathrm{mol} / 1 ; 0 \cdot 2-1 \cdot 2 \mathrm{mg} / 100 \mathrm{ml}$ ) and oesophageal varices developed. In April 1978 transiliac biopsy showed severe osteomalacia, and in June treatment began with oral $1 \alpha-\mathrm{OHD}_{3} 2 \mu \mathrm{g}$ daily. Serum calcium concentration was measured monthly and a repeat bone biopsy was performed in December 1978. Renal function was normal throughout. She was also receiving frusemide $80 \mathrm{mg}$ twice daily, potassium supplements, diphenoxylate, and parenteral vitamins $\mathrm{A}$ and $\mathrm{K}$.

Fasting serum alkaline phosphatase activity and calcium, albumin phosphate, and bilirubin concentrations were measured on an autoanalyser (SMA 12/60), the serum calcium concentration being corrected for serum albumin value. ${ }^{3}$ Plasma immunoreactive parathyroid hormone (PTH) values were measured by radioimmunoassay ${ }^{4}$ (MRC antiserum code BW 211/41). Undecalcified sections of transiliac biopsy specimens $(8 \mu \mathrm{m})$ were quantified with a Zeiss 25 -point eyepiece graticule. Calcification fronts were shown both by $1 \%$ toluidine-blue staining and by fluorescence microscopy of unstained sections after giving $900 \mathrm{mg}$ demethylchlortetracycline by mouth 48 hours before biopsy. Hyperparathyroidism was assessed qualitatively. Control values were obtained in biopsy specimens from seven women aged 54-73 years (mean 61.8); three were from healthy women and four from women who had died suddenly with no previous immobilisation or history of metabolic bone disease.

After treatment with $1 \alpha-\mathrm{OHD}_{3}$ the serum calcium and phosphate concentrations increased and the serum alkaline phosphatase activity lessened (see table). The plasma PTH concentration, which was high before treatment, was normal six months later. Liver function, as judged from serum bilirubin and albumin concentrations, remained stable during treatment. Hypercalcaemia was never encountered at monthly monitoring. The first bone biopsy showed severe osteomalacia with evidence of secondary hyperparathyroidism; after treatment with $1 \alpha-\mathrm{OHD}_{3}$ for six months the histological appearances had returned to normal.

Serum biochemical values and quantitative bone histology before and after treatment with $1 \alpha-O H D_{3}$. (Normal values for bone histology expressed as means $\pm S D$ )

\begin{tabular}{|c|c|c|c|}
\hline & $\begin{array}{c}\text { Before } \\
\text { treatment }\end{array}$ & $\begin{array}{c}\text { After } \\
\text { treatment }\end{array}$ & $\begin{array}{c}\text { Normal } \\
\text { value }\end{array}$ \\
\hline $\begin{array}{l}\text { Corrected serum calcium concentration }(\mathrm{mmol} / \mathrm{l}) \\
\text { Serum phosphate concentration (mmol/l) } \\
\text { Serum alkaline phosphatase activity (IU } / 1) \\
\text { Plasma parathyroid hormone concentration }(\mu \mathrm{g} / 1) \\
\text { Cancellous bone volume }(\% \text { total sectional }\end{array}$ & $\begin{array}{l}2 \cdot 29 \\
0 \cdot 92 \\
1390 \\
2 \cdot 3\end{array}$ & $\begin{array}{l}2 \cdot 41 \\
1 \cdot 1 \\
910 \\
0 \cdot 44\end{array}$ & $\begin{array}{c}2 \cdot 3-2 \cdot 6 \\
0 \cdot 8-1 \cdot 4 \\
30-85 \\
0-0 \cdot 9\end{array}$ \\
\hline $\begin{array}{ll}\text { volume }) & \ldots \\
\text { Osteoid volume }(\% \text { total cancellous volume }) & \ldots \\
\text { Osteoid surface }(\%, \text { total cancellous surface) } & \ldots \\
\text { Calcification fronts }(\% \text { total osteoid surface }) & \ldots\end{array}$ & $\begin{array}{r}29 \cdot 7 \\
25 \cdot 8 \\
86 \cdot 5 \\
5 \cdot 4\end{array}$ & $\begin{array}{r}10 \cdot 7 \\
4 \cdot 7 \\
18 \cdot 1 \\
67 \cdot 5\end{array}$ & $\begin{array}{r}24 \cdot 9 \pm 18 \cdot 8 \\
1 \cdot 7 \pm 3 \cdot 4 \\
22 \cdot 3 \pm 29 \cdot 5 \\
70 \cdot 1 \pm 3 \cdot 5\end{array}$ \\
\hline
\end{tabular}

Conversion: SI to traditional units-Serum calcium: $1 \mathrm{mmol} / 1 \approx 4.0 \mathrm{mg} / 100 \mathrm{ml}$. Conversion: SI to traditional units - Serum
Serum phosphate: $1 \mathrm{mmol} / 1 \approx 3.0 \mathrm{mg} / 100 \mathrm{ml}$.

\section{Comment}

This case shows that oral $1 \alpha-\mathrm{OHD}_{3}$ may be rapidly effective in healing severe osteomalacia associated with chronic cholestasis and suggests that even in severe liver disease adequate intestinal absorption and hepatic 25 -hydroxylation of the vitamin may occur to produce a therapeutic effect, provided that a large enough dose is given. These findings accord with the report that either oral $25-\mathrm{OHD}_{3}$ or parenteral vitamin $\mathrm{D}_{2}$ may heal osteomalacia associated with $\mathrm{PBC} .^{1}$
There is no evidence that $1 \alpha-\mathrm{OHD}_{3}$ is more effective than other forms of vitamin $\mathrm{D}$ in healing hepatic osteomalacia but it has important practical advantages; its short biological half life and comparatively narrow therapeutic dose range enables the correct dose to be established more quickly, and hypercalcaemia associated with overdosage may be more rapidly reversed than with the parent vitamin. ${ }^{5}$ Hypercalcaemia did not occur in our patient but is a potential hazard of any vitamin $\mathrm{D}$ treatment and may appear only after bone healing has occurred. We conclude that oral $1 \alpha-\mathrm{OHD}_{3}$ is safe and effective in healing osteomalacia associated with PBC.

We thank J Sainsbury Ltd and the Special Trustees of St Thomas's Hospital for financial support. We are grateful to Dr J S Woodhead, Welsh National School of Medicine, Cardiff, for measuring plasma PTH; to Dr Roger Williams for allowing us to study the patient; and to Adrian Webb for preparing the bone histological sections.

Requests for reprints should be addressed to: Dr J E Compston, Gastrointestinal Research Unit, Rayne Institute, St Thomas's Hospital, London SE1 7EH.

${ }^{1}$ Compston, J E, Horton, L W L, and Thompson, R P H, Gut, 1979, 20, 133.

${ }^{2}$ Holick, M F, et al, fournal of Biological Chemistry, 1976, 251, 1020.

3 Payne, R B, et al, British Medical fournal, 1973, 4, 643.

4 Addison, G M, et al, Endocrinology, 1971, 49, 521.

${ }^{5}$ Kanis, J A, and Russell, R G G, British Medical fournal, 1977, 1, 78.

(Accepted 8 June 1979)

Gastrointestinal Research Unit, Rayne Institute, St Thomas's Hospital, London SE1 7EH

JULIET E COMPSTON, BSC, MRCP, senior research registrar

Liver Unit, King's College Hospital, London SE5 9RS

JOHN P CROWE, PHD, MRCPI, lecturer (present appointment: consultant physician, Mater Misericordiae Hospital, Dublin 7)

Department of Surgical Pathology, St Thomas's Hospital, London SE1 7EH

L W L HORTON, MRCP, MRCPATH, senior lecturer (present appointment: consultant pathologist, Royal Berkshire Hospital, Reading, Berks)

\section{An unusual case of respiratory obstruction due to inhalation of the epiglottis with an unusual attempt at self-treatment}

We report an unusual cause of respiratory obstruction, in which the diagnosis was originally missed because of the anaesthetic technique used.

\section{Case report}

After suffering with a sore throat for seven days a 36-year-old man experienced rapidly increasing difficulty in breathing. He had read in a newspaper that laryngotomy could be a life-saving operation and had attempted to perform this on himself unsuccessfully. Fortunately he was found by a friend in time to bring him to hospital.

On admission there was obvious upper airway obstruction with lacerations in the neck skin. He was seen by a junior anaesthetist, who, not realising the potential dangers of this procedure in a patient with severe airway obstruction, induced anaesthesia with Althesin and suxamethonium and intubated an apparently normal larynx. The larynx was examined in theatre three hours later under anaesthesia with muscular paralysis, but apart from slight inflammation of the mucosa no abnormality was seen. The superficial skin lacerations were sutured. After extubation the patient's airway became progressively and rapidly obstructed. Anaesthesia was re-established, and examination under deep anaesthesia without muscular paralysis showed that the epiglottis was flaccid and flopped backwards with each inspiration to obstruct the laryngeal inlet completely. This was noted to give rise to a cogwheel pattern of inspiratory obstruction, with unobstructed expiration.

The patient was reintubated for $\mathbf{4 8}$ hours and then re-examined in theatre. There was no visible abnormality. After extubation, however, on return of spontaneous breathing the epiglottis appeared no longer flaccid, and after 12 months the patient has suffered no further airway obstruction after upper respiratory tract infections. 


\section{Comment}

Following the observation of the flaccid epiglottis investigation failed to show an obvious anatomical explanation for the phenomenon. A partial epiglottectomy was considered but did not prove necessary. Epiglottitis as described has always been accompanied by oedema. Possibly the rigidity and elasticity of the cartilage may be affected. It has been shown radiologically that the epiglottis becomes more curled in adult epiglottitis. ${ }^{2}$ Inflammation might also alter the pre-epiglottic fatty tissue at the base of the structure, influencing its position and movement in some subtle way. Alternatively, a viral neuromuscular condition might alter the co-ordination of the opposing thyroepiglottic and aryepiglottic muscles. ${ }^{3}$

We noticed in this patient a characteristic cogwheel pattern of inspiratory obstruction; since then this pattern has been noted by one of us six times in patients recovering from anaesthesia. Only one of these was anaesthetised deeply enough to allow direct laryngoscopy, and in this patient a similar but less severe appearance of "epiglottic impotence" was seen. In the other patients irsertion of a nasopharyngeal airway long enough to hold the epiglottis forwards has relieved the obstruction on four out of five occasions. This obstruction (which would usually have been diagnosed previously as laryngeal spasm) might also have been due to incoordinate action of the muscles attached to the epiglottis.

${ }^{1}$ Kander, P L, and Richards, S H, fournal of Laryngology and Otology, 1977,91 , No 4 .

${ }^{2}$ Schabel, S, Katzberg, R, and Burgener, F, Radiology, 1977, 122, 601.

3 Gray's Anatomy, 35th edn, p 1181. London, Longman, 1973.

(Accepted 7 fune 1979)

Cheltenham General Hospital, Cheltenham, Glos

MICHAEL HARDINGHAM, MB, FRCS, consultant ENT surgeon

PETER N YOUNG, MB, FFARCS, consultant anaesthetist

\section{Serum bilirubin and hepatic enzyme induction}

Patients treated with phenobarbitone, a known enzyme inducer, have lower plasma total bilirubin concentrations than controls. ${ }^{1}$ Measurement of bilirubin in a single blood sample might therefore provide a simple and useful index of liver enzyme induction.

This study aimed to measure the serum concentrations of conjugated and unconjugated bilirubin, calculate the ratio of conjugated to unconjugated bilirubin, and compare it with the antipyrine half life, a recognised test of enzyme induction, in carefully selected patients on long-term treatment with oral phenobarbitone or phenytoin and in normal controls.

\section{Patients, methods, and results}

Patients who had been treated for over three months with phenytoin alone, phenobarbitone alone, or a combination of both were selected for study. Patients, and age- and sex-matched normal volunteer controls, were excluded if they were under 16 or over 65 years, taking any other medication, or if abnormalities of haemoglobin, urea, electrolytes, aspartate aminotransferase, or alkaline phosphatase were detected. Venous blood $(10 \mathrm{ml})$ was taken for bilirubin estimation at 8.30-9.30 am from fasting controls and drug-treated patients. Antipyrine half lives ${ }^{2}(18 \mathrm{mg} / \mathrm{kg}$ body weight) were measured over 12 hours on the same day. Serum total bilirubin and conjugated bilirubin were measured by a modification of the method of Malloy and Evelyn. ${ }^{3}$ Unconjugated bilirubin was calculated by subtracting conjugated from total bilirubin. The samples were submitted for "blind" analysis in random order.

The seven patients receiving daily phenytoin alone (range $200-800 \mathrm{mg}$, mean $240 \mathrm{mg}$ ), the 14 taking phenobarbitone alone (range $60-90 \mathrm{mg}$, mean $80 \mathrm{mg}$ ), and the seven taking both (range of phenytoin 100-300 $\mathrm{mg}$, mean $200 \mathrm{mg}$; range of phenobarbitone $30-150 \mathrm{mg}$, mean $90 \mathrm{mg}$ ) had significantly lower serum unconjugated bilirubin and antipyrine half lives than the 22 controls ( $\mathbf{P}<0.001$; Student's $t$ test; table). The correlation coefficient of serum unconjugated bilirubin and antipyrine half life was $0.635(P<0.001)$. The drug-treated group also had significantly raised serum conjugated bilirubin concentrations and ratios of conjugated to unconjugated bilirubin. There was little overlap between the unconjugated bilirubin values for the drug-treated and control groups, with only one drug-treated patient having a concentration over $7 \mu \mathrm{mol} / 1$ and only one control having a concentration below $7 \mu \mathrm{mol} / 1$.

\section{Comment}

Under the conditions of this study a fasting value for serum unconjugated bilirubin correlated closely with the antipyrine half life. Estimating unconjugated bilirubin is simple, and the procedure is less time-consuming and cumbersome than methods which are commonly used to assess hepatic enzyme induction, such as estimating antipyrine half life, urinary D-glucaric acid excretion, or 6- $\beta$-hydroxycortisol excretion and liver biopsy.

Phenytoin and phenobarbitone cause induction of the hepatic enzyme bilirubin uridine diphosphate glucuronyl transferase." Increased activity of this enzyme reduces plasma unconjugated bilirubin and may increase plasma conjugated bilirubin concentrations depending on the rate of excretion in bile. The unconjugated bilirubin concentration in an individual patient appears to be a more reliable indication of this effect than the conjugated bilirubin concentration because there was less overlap between the values in the drug-treated patients and those in the controls. Clearly further studies are required to determine the usefulness of measurement of serum unconjugated bilirubin in patients with induction of hepatic enzymes caused by other drugs. Measurement of bilirubin will not be a reliable test of enzyme induction in patients with predictable disturbances of bilirubin concentrations-for example, those with hepatobiliary disease or anaemia. The timing of venesection is important because of diurnal variations in serum bilirubin."

We thank Dr Allan Downie, Dr J E C Hern, and the patients and volunteers for their help with this study.

${ }^{1}$ Hunter, J, et al, Lancet, 1971, 1, 572.

2 Brodie, B B, and Axelrod, J, Fournal of Pharmacology and Experimental Therapeutics, 1956, 98, 97.

${ }^{3}$ Malloy, H T, and Evelyn, K A, fournal of Biological Chemistry, 1937, 119, 481.

* Arias, I M, et al, Annals of the New York Academy of Sciences, 1963, 111, 274.

5 Scott, A K, et al, unpublished data.

(Accepted 1 fune 1979)

Department of Therapeutics and Clinical Pharmacology, University of Aberdeen, Aberdeen AB9 2ZB

A K SCOTT, MRCP, lecturer

T A JEFFERS, MRCP, clinical senior lecturer

J C PETRIE, MRCP, senior lecturer

Section of Pharmacology, Heriot-Watt University, Edinburgh EH1 2HJ

J C GILBERT, PHD, professor of pharmacology

Serum bilirubin concentrations and antipyrine half life times in 22 controls and 28 treated paticnts

\begin{tabular}{|c|c|c|c|c|}
\hline & \multirow{2}{*}{ Controls (22) } & \multicolumn{3}{|c|}{ Patients on: } \\
\hline & & Phenobarbitone (14) & Phenytoin (7) & Both (7) \\
\hline Unconjugated bilirubin $(\mu \mathrm{mol} \mathrm{l})$ & $11 \cdot 73=0.51$ & $4.42=0.51$ & $4.08+0.68$ & $4 \cdot 42 \div 0.34$ \\
\hline Conjugated bilirubin $(\mu \mathrm{mol} \mathrm{l})$ & $0 \cdot 21 \doteq 0 \cdot 07$ & $\begin{array}{c}P<0.001 \\
0.68<0.17 \\
P<0.01\end{array}$ & $\begin{array}{l}P<0.001 \\
1.87=0.85 \\
P<0.002\end{array}$ & $\begin{array}{c}P<0.001 \\
0.68=0.24 \\
P<0.01\end{array}$ \\
\hline Ratio $(\mathrm{C}: \mathrm{U})$ & $0 \cdot 01$ & $0 \cdot 24=0 \cdot 11$ & $\begin{array}{l}P<0.002 \\
0.66 \\
P-0.34\end{array}$ & $\begin{array}{l}P<0.01 \\
0.19 \pm 0.05\end{array}$ \\
\hline Antipyrine $t !(h)$ & $13 \cdot 8=1 \cdot 2$ & $\begin{array}{c}P<0 \cdot 01 \\
8 \cdot 7 \pm 0.8 \\
P<0.005\end{array}$ & $\begin{array}{l}\mathrm{P}<0.002 \\
7 \cdot 4 \cdot 1 \cdot 07 \\
\mathrm{P}<0.005\end{array}$ & $\begin{array}{l}\mathrm{P}<0.001 \\
6.4 \pm 0.31 \\
\mathrm{P}<0.001\end{array}$ \\
\hline
\end{tabular}

